\title{
Pre-Sleep Casein Supplementation, Metabolism, and Appetite: A Systematic Review
}

\author{
Justin Dela Cruz * and David Kahan \\ School of Exercise and Nutritional Sciences, San Diego State University, San Diego, CA 92182, USA; \\ dkahan@sdsu.edu \\ * Correspondence: justindelacruzzz@gmail.com
}

Citation: Dela Cruz, J.; Kahan, D. Pre-Sleep Casein Supplementation, Metabolism, and Appetite: A Systematic Review. Nutrients 2021, 13, 1872. https://doi.org/10.3390/ nu13061872

Academic Editor: Megan A. McCrory

Received: 18 April 2021

Accepted: 27 May 2021

Published: 30 May 2021

Publisher's Note: MDPI stays neutral with regard to jurisdictional claims in published maps and institutional affiliations.

Copyright: (c) 2021 by the authors. Licensee MDPI, Basel, Switzerland. This article is an open access article distributed under the terms and conditions of the Creative Commons Attribution (CC BY) license (https:// creativecommons.org/licenses/by/ $4.0 /)$.

\begin{abstract}
Protein intake is an important factor for augmenting the response to resistance training in healthy individuals. Although food intake can help with anabolism during the day, the period of time during sleep is typically characterized by catabolism and other metabolic shifts. Research on the application of nighttime casein protein supplementation has introduced a new research paradigm related to protein timing. Pre-sleep casein supplementation has been attributed to improved adaptive response by skeletal muscle to resistance training through increases in muscle protein synthesis, muscle mass, and strength. However, it remains unclear what the effect of this nutritional strategy is on non-muscular parameters such as metabolism and appetite in both healthy and unhealthy populations. The purpose of this systematic review is to understand the effects of pre-sleep casein protein on energy expenditure, lipolysis, appetite, and food intake in both healthy and overweight or obese individuals. A systematic review following PRISMA guidelines was conducted in CINAHL, Cochrane, and SPORTDiscus during March 2021, and 11 studies met the inclusion criteria. A summary of the main findings shows limited to no effects on metabolism or appetite when ingesting 24-48 g of casein $30 \mathrm{~min}$ before sleep, but data are limited, and future research is needed to clarify the relationships observed.
\end{abstract}

Keywords: casein; sleep; metabolism; appetite; exercise

\section{Introduction}

Timing of food intake is a major component influencing individual total daily intake. Food consumption primarily in the earlier part of the day is correlated with decreased overall daily intake, whereas consumption closer to nighttime can increase overall daily intake [1]. This relationship is affected in part by macronutrient intake, as consumption of either carbohydrates, fats, or proteins in the morning all have a much higher rate of satiation compared to nighttime consumption [2]. With such prominent effects of timing on total daily food intake, the overconsumption of food in the latter half of the day can be linked to excessive weight gain. Nighttime eating behaviors are a contributing factor to additional yearly weight gain in obese women [3]. This relationship may be linked to physiological changes dictated by the circadian rhythm that cause insulin sensitivity and energy expenditure to decrease in the latter half of the day compared to in the morning $[4,5]$. Furthermore, this issue may be exacerbated, as chronic nighttime eating behaviors can also develop into disordered eating patterns such as nighttime eating syndrome (NES) or nocturnal eating/drinking syndrome (NEDS) [6].

Although weight gain may be linked to increased food intake during nighttime eating behaviors, this may also be affected by metabolic adaptations that occur during sleep. Metabolic processes are altered during times of sleep through a reduction in both energy expenditure and fat oxidation [7]. Nighttime eating can also negatively alter metabolism by shifting fuel utilization away from fat and toward carbohydrates [8]. However, the detrimental effects of nighttime feeding that come with the classic consumption of large 
calorie-dense meals with mixed macronutrient composition can potentially be mitigated by the consumption of small nutrient-dense and low-calorie meals that focus on one specific macronutrient [9].

Recent research has delved into the beneficial effects of nighttime single macronutrient consumption, specifically protein intake in close proximity to sleep, and its effects on muscular adaptations from resistance training. It is important to note that the consumption of protein significantly decreases the rate of total body protein breakdown [10], which supports the theoretical framework for consuming protein around a time of catabolism such as sleep. One of the first research studies to look at pre-sleep intake of casein protein reported the enhancement of protein synthesis rates as a skeletal muscle mechanism for recovery after resistance training [11]. This was later confirmed in one other study [12], although another study later differentiated that muscle connective tissue protein synthesis rate was unaffected [13]. Another study found that pre-sleep casein supplementation augments protein synthesis rates via the mechanism of increasing the incorporation of amino acids [14]. These findings may explain the underlying mechanisms as to why one study done on pre-sleep casein supplementation was shown to increase muscle crosssectional area, type 2 fiber size, and strength in healthy young men during a 12-week resistance training program [15]. Even with what is known about altered metabolism during sleep and the potential risks associated with nighttime eating on weight gain, presleep casein supplementation does not increase fat mass in a healthy active population [16] This nutritional strategy presents an advantageous perspective for increasing protein intake during the nighttime in a healthy active population without any detriments to body composition.

A recent systematic review looked at the effects of pre-sleep casein supplementation on muscle adaptations in healthy individuals and reported significant increases in whole body protein synthesis observed in five studies [17]. However, this systematic review had limited evidence regarding other muscle adaptations, with only one included study reporting significant findings in muscle cross-sectional area, type 2 fiber size, and strength [17]. Furthermore, there have been no reviews published regarding the impact of this nutritional strategy on non-muscular parameters such as metabolism and appetite. Dairy foods such as milk, cheese, or yogurt have shown significant effects on reducing appetite [18]. Casein has been reported to decrease energy intake to a greater extent than whey protein [19]. Although casein consumption has been shown to suppress appetite in overweight individuals through elevation of ghrelin and CCK [20], there is a lack of investigation specifically into the impact of pre-sleep casein supplementation on overweight or obese individuals. The aim of this systematic review is to synthesize research findings on the effect of pre-sleep casein supplementation on metabolism and appetite in both healthy and unhealthy populations.

\section{Materials and Methods}

\subsection{Systematic Search Strategy}

The systematic search for this study followed PRISMA (Preferred Reporting Items for Systematic Reviews and Meta-Analyses) guidelines. Table 1 presents the Population, Intervention, Comparison, Outcome, and Setting (PICOS) parameters that were used to define the scope of research included.

A systematic search was conducted in March 2021 by one independent author (J.D.C.) and used the following three online databases: CINAHL, Cochrane, and SPORTDiscus. In order to identify all relevant articles published on the topic, no filters were applied.

Titles/abstracts/keywords were identified using the following Boolean search operators: ("casein" OR "protein") AND ("sleep" OR "overnight" OR "pre-sleep" OR "presleep" OR "prior to sleep*" OR "before sleep*") AND ("metabol*" OR "energy expenditure" OR "caloric expenditure" OR "basal metabolic rate" OR "BMR" OR "metabolic rate" OR "resting energy expenditure" OR "REE" OR "resting metabolic rate" OR "RMR" OR "lipolysis" OR "fat metabolism" OR "fat oxidation" OR "beta oxidation" OR " $\beta$ oxidation" OR "fat 
breakdown" OR "hunger" OR "appetite" OR "satiety" OR "energy intake" OR "food intake" OR "food consumption").

Table 1. PICOS (Population, Intervention, Comparison, Outcome, Setting) criteria for inclusion of studies.

\begin{tabular}{cc}
\hline Parameter & Description \\
\hline Population & Human trials in adults or elderly ( $\geq 18$ years old) \\
\hline Intervention & Casein supplementation before sleep \\
\hline Comparison & Casein vs. control (placebo, carbohydrate, or water) \\
\hline Outcome & Metabolism or appetite \\
\hline Setting (Study Design) & Randomized control trial \\
\hline
\end{tabular}

\subsection{Eligibility Criteria}

Articles were included in this systematic review if they met the following criteria: (1) randomized control trial; (2) sample of adult/elderly individuals ( $\geq 18$ years old); (3) casein protein was consumed pre-sleep; (4) casein supplementation was compared to a control treatment; and (5) assessed the effect of pre-sleep casein supplementation on metabolism or appetite. The exclusion criteria were (1) no pre-sleep casein supplementation consumed; (2) no metabolic or appetite parameters assessed; and (3) abstracts, reviews, manuscripts, thesis, books, letters, conference posters, or public seminars.

Casein intake was considered as pre-sleep if it was the last meal consumed during that day. Metabolism was used as an umbrella term and operationally defined as (1) any form of energy expenditure or metabolic rate, or (2) lipolysis or fat oxidation. Appetite was operationally defined as (1) appetite or satiety, (2) hunger or desire to eat, or (3) food intake. A narrative synthesis of the results from the selected studies included in this review was classified into the metabolic and appetite parameters previously defined.

\section{Results}

\subsection{Systematic Search and Study Selection}

The systematic search and article selection process is depicted in Figure 1. Preliminary searching across the three databases identified a total of 1964 articles that were exported into the electronic software program Zotero for literature management. After duplicates were removed, 1904 articles remained, and all articles were published between 1978 and 2021, but we did not take into account articles from February to March 2021. Articles identified were assessed using the inclusion criteria, which condensed the search down to 44 articles that were exported into the online electronic program Covidence for systematic review management. During the screening process, a secondary round of deduplication $(n=23)$ and evaluation of article title/abstract that did not meet inclusion criteria $(n=8)$ was completed. A total of 13 articles remained for full-text evaluation for eligibility.

Full-text evaluation for eligibility excluded four articles for either improper publication format (manuscript or conference poster; $n=3$ ) or if the study did not measure any metabolic or appetite parameters $(n=1)$. Additional studies retrieved from the reference section of the 13 original articles were also screened for eligibility and added to the systematic review $(n=2)$. A total of 11 articles were included in this systematic review for data extraction and synthesis of the main results. 


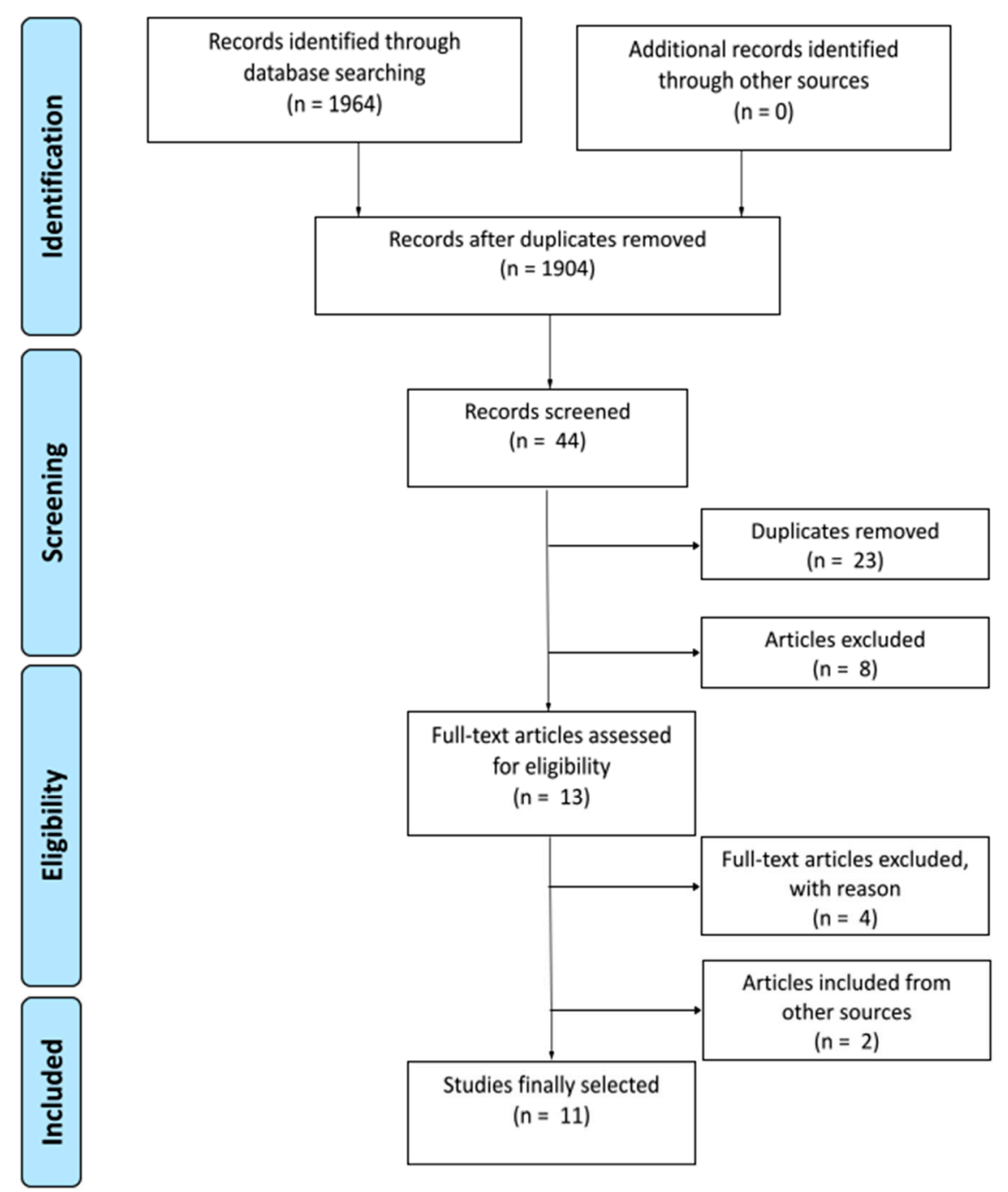

Figure 1. PRISMA flow diagram for study selection process of pre-sleep casein supplementation articles.

\subsection{Descriptive Data and Characteristics of Selected Studies}

The main characteristics of the selected studies in this systematic review are recorded in Table 2. All studies were randomized control trials, and 10 of the 11 studies were blinded (nine double blind; one single blind). Five out of the 11 studies included a crossover design. Casein consumed in the selected studies ranged between 24 and $48 \mathrm{~g}$ doses. Eight out of the 11 studies used a casein protein drink as the food medium for pre-sleep supplementation, and the remaining three studies used either cottage cheese or a casein supplement mixture (casein with whey and carbohydrate or casein with tryptophan).

Table 3 lists the descriptive details of the studies that included an exercise trial or meal standardization. Six out of the 11 studies included a standardized single meal or entire day meal plan based on the participants' estimated energy expenditure. Only four out of the 11 studies included an exercise trial as part of the research protocol.

Six out of the 11 studies observed metabolic or appetite parameters in healthy young adult samples, four studies were conducted in overweight or obese young adult samples, and one study was conducted in a healthy elderly adult sample. In order to differentiate the main findings, Table 4 categorized main results into metabolic and appetite parameters measured (i.e., next-day appetite/hunger/satiety/food intake, energy expenditure/metabolic rate, and lipolysis/fat oxidation) and were further subdivided into sample population (i.e., healthy young adults, overweight or obese young adults, or healthy elderly adults). 
Table 2. Main characteristics of included studies related to pre-sleep casein supplementation effects on metabolism and appetite.

\begin{tabular}{|c|c|c|c|c|c|c|c|c|}
\hline $\begin{array}{c}\text { Study } \\
\text { (Author, Year) }\end{array}$ & Subjects & $\begin{array}{l}\text { Sample Size } \\
\text { (Mean Age) }\end{array}$ & Study Design & $\begin{array}{c}\text { Metabolic Parameters } \\
\text { Measured }\end{array}$ & Protein Source & \multicolumn{2}{|c|}{ Exercise Trial Included? } & $\begin{array}{l}\text { Standardized } \\
\text { Meal? }\end{array}$ \\
\hline $\begin{array}{l}\text { Kinsey et al., } \\
2014 \text { [21] }\end{array}$ & $\begin{array}{l}\text { Obese and } \\
\text { overweight women }\end{array}$ & $44(29)$ & DRCT & $\begin{array}{l}\text {-Appetite } \\
\text {-Metabolism (RMR) }\end{array}$ & Casein & No & & No \\
\hline $\begin{array}{l}\text { Madzima et al., } \\
2014 \text { [22] }\end{array}$ & Active men & $11(24)$ & DRCT, CD & $\begin{array}{l}\text {-Hunger, satiety, } \\
\text { desire to eat } \\
\text {-Metabolism (REE) }\end{array}$ & Casein & No & & No \\
\hline $\begin{array}{l}\text { Ormsbee et al., } \\
2015 \text { [23] }\end{array}$ & Obese women & $37(29)$ & DRCT & $\begin{array}{l}\text {-Appetite } \\
\text {-Metabolism }\end{array}$ & Casein & Yes & & No \\
\hline $\begin{array}{l}\text { Kinsey et al., } \\
2016 \text { [24] }\end{array}$ & Obese men & $12(27)$ & DRCT & $\begin{array}{l}\text {-Appetite } \\
\text {-Metabolism } \\
\text {-SCAAT lipolysis }\end{array}$ & Casein & No & & Yes \\
\hline $\begin{array}{l}\text { Lay et al., } \\
2018 \text { [25] }\end{array}$ & Overweight men & $8(24)$ & DRCT, CD & $\begin{array}{l}\text {-Hunger, fullness, } \\
\text { desire to eat } \\
\text {-Next day ad libitum } \\
\text { breakfast }\end{array}$ & $\begin{array}{l}\text { Casein mixture } \\
\text { with whey and } \\
\text { carbohydrate }\end{array}$ & No & & Yes \\
\hline $\begin{array}{l}\text { Leyh et al., } \\
2018 \text { [26] }\end{array}$ & Active women & $10(23)$ & DRCT, CD & $\begin{array}{l}\text {-Appetite } \\
\text {-Metabolism (REE) }\end{array}$ & $\begin{array}{l}\text { Casein and } \\
\text { cottage cheese }\end{array}$ & No & & Yes \\
\hline $\begin{array}{l}\text { Madzima et al., } \\
2018 \text { [27] }\end{array}$ & Active women & $9(25)$ & DRCT, CD & -Metabolism & Casein & Yes & & No \\
\hline $\begin{array}{l}\text { Trommelen et al., } \\
2018 \text { [28] }\end{array}$ & Active men & $36(23)$ & DRCT & $\begin{array}{l}\text {-Next morning } \\
\text { hunger and satiety }\end{array}$ & Casein & & Yes & Yes \\
\hline $\begin{array}{l}\text { Allman et al., } \\
2020 \text { [29] }\end{array}$ & Active men & $13(22)$ & DRCT, CD & $\begin{array}{l}\text {-Metabolism (REE) } \\
\text {-SCAAT lipolysis }\end{array}$ & Casein & & Yes & Yes \\
\hline $\begin{array}{l}\text { Morehen et al., } \\
2020 \text { [30] }\end{array}$ & $\begin{array}{l}\text { Older men and } \\
\text { women }\end{array}$ & $12(71)$ & SRCT & $\begin{array}{l}\text {-Appetite } \\
\text {-Metabolism } \\
\text {-Next day } \\
\text { ad libitum breakfast }\end{array}$ & Casein & & No & Yes \\
\hline $\begin{array}{l}\text { Nelson et al., } \\
2021 \text { [31] }\end{array}$ & Active women & $13(23)$ & $\mathrm{RCT}$ & $\begin{array}{l}\text {-Appetite } \\
\text {-Metabolism }\end{array}$ & Casein mixture witl & ptophan & No & No \\
\hline
\end{tabular}

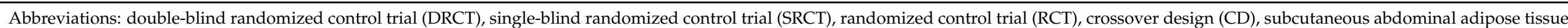
(SCAAT), resting metabolic rate (RMR), resting energy expenditure (REE). 
Table 3. Descriptive characteristics of studies that included meal standardization or resistance exercise.

\begin{tabular}{|c|c|c|c|c|c|}
\hline \multirow[t]{2}{*}{ Study (Author, Year) } & \multicolumn{3}{|c|}{ Exercise Trial } & \multicolumn{2}{|c|}{ Meal Standardization } \\
\hline & Exercise Modality & Exercise Trial Length & Exercise Protocol & $\begin{array}{c}\text { Single Meal } \\
\text { or Entire Day }\end{array}$ & $\begin{array}{c}\text { Energy Expenditure } \\
\text { Estimate }\end{array}$ \\
\hline Ormsbee et al., 2015 [23] & $\begin{array}{l}\text { Resistance training } \\
\text { and HIIT }\end{array}$ & $\begin{array}{l}4 \text { week ( } 3 \text { days / week } \\
\text { nonconsecutively) } \\
2 \text { days of resistance training } \\
\text { and } 1 \text { day of HIIT }\end{array}$ & $\begin{array}{l}\text { Resistance training } \\
\text {-Total of } 3 \text { sets per exercise (first } 2 \text { sets for } \\
10 \text { repetitions and last set performed to } \\
\text { muscular exhaustion). } \\
\text {-Exercises performed included: chest press, } \\
\text { seated row, leg press, shoulder press, leg } \\
\text { extension, and leg curl. } \\
\text {-Chest press and leg press at } 70-85 \% \text { of } 1 R M \\
\text { and the remaining exercises at a weight that } \\
\text { could be lifted for } 10-12 \text { repetitions. } \\
\text {-Total of } 90-120 \text { s rest periods. } \\
\text { HIIT } \\
\text {-Based on individual RPE scale (1-10). } \\
\text {-Self-selected machine (cycle ergometer, } \\
\text { treadmill, or elliptical trainer). } \\
\text {-Total of } 4 \text { HIIT cycles performed for a total } \\
\text { of } 20 \text { min. } \\
\text {-HIIT cycle: warm up at RPE } 5 \text { ( } 2 \text { min), } \\
\text { increased by } 1 \text { RPE every minute until } \\
\text { reaching RPE } 9 \text {, RPE reduced to } 6 \text { for } 1 \text { min, } \\
\text { repeated ramping cycle up to RPE } 9 .\end{array}$ & & \\
\hline Lay et al., 2018 [25] & & & & Entire day & $\begin{array}{l}\text {-Distribution of } 50 \% \text { CHO, } \\
32 \% \text { FAT, } 18 \% \text { PRO } \\
\text {-Energy matched to the } \\
\text { participants' average evening } \\
\text { meal intake from } \\
\text { their food record. }\end{array}$ \\
\hline Leyh et al., 2018 [26] & & & & Single meal & $\begin{array}{l}\text { Energy expenditure estimate } \\
\text { and macronutrient } \\
\text { distribution details not stated. }\end{array}$ \\
\hline
\end{tabular}


Table 3. Cont

\begin{tabular}{|c|c|c|c|c|c|}
\hline \multirow[t]{2}{*}{ Study (Author, Year) } & \multicolumn{3}{|c|}{ Exercise Trial } & \multicolumn{2}{|c|}{ Meal Standardization } \\
\hline & Exercise Modality & Exercise Trial Length & Exercise Protocol & $\begin{array}{c}\text { Single Meal } \\
\text { or Entire Day }\end{array}$ & $\begin{array}{c}\text { Energy Expenditure } \\
\text { Estimate }\end{array}$ \\
\hline $\begin{array}{c}\text { Madzima et al., } \\
2018 \text { [27] }\end{array}$ & Resistance training & Single day session & $\begin{array}{l}\text {-Exercises performed: chest press, leg press, } \\
\text { lat pull-down, shoulder press, leg extension, } \\
\text { and leg curl. } \\
\text {-Performed at metronome cadence of } \\
30 \text { beats } / \text { minute (ratio of } 2: 2 \mathrm{~s} \\
\text { concentric and eccentric). } \\
\text {-Total of } 3 \text { sets per exercise (first two sets for } \\
10 \text { repetitions and last set performed to } \\
\text { muscular exhaustion). } \\
\text {-Exercises performed at } 60 \% \text { of } 1 \mathrm{RM} \text {. }\end{array}$ & & \\
\hline Allman et al., 2020 [29] & Resistance training & Single day session & $\begin{array}{l}\text {-Exercises performed: back squat, bench } \\
\text { press, Romanian deadlift, bent-over row, } \\
\text { shoulder press, and reverse lunges. } \\
\text {-Total of } 4 \text { sets of } 10 \text { repetitions (Set } 1: 40 \% \text { of } \\
\text { 1RM, Set } 2-4: 65 \% \text { at } 65 \% 1 \mathrm{RM}) \text {. }\end{array}$ & Entire day & $\begin{array}{l}\text {-Distribution of } 40 \% \mathrm{CHO} \text {, } \\
30 \% \text { FAT, } \% 30 \mathrm{PRO} \\
\text {-Energy matched to the } \\
\text { participants' Cunningham } \\
\text { equation calculation. }\end{array}$ \\
\hline
\end{tabular}


Table 4. Summary of main results from included studies related to pre-sleep casein supplementation effects on metabolism and appetite.

\begin{tabular}{|c|c|c|c|c|}
\hline Study (Author, Year) & $\begin{array}{l}\text { Next-Morning Appetite, } \\
\text { Hunger, and Satiety }\end{array}$ & Metabolism & Lipolysis & Next-Morning Food Intake \\
\hline \multicolumn{5}{|l|}{ Healthy young adult } \\
\hline Madzima et al., 2014 [22] & $\begin{array}{l}\text { No effect on appetite sensations } \\
\qquad(p>0.05)\end{array}$ & $\begin{array}{l}\text { No group } \mathrm{x} \text { time interaction for } \\
\text { RMR }(p>0.05) \text {. } \\
\text { Mean VO2 significantly greater in } \\
\text { casein than in control }(p<0.0001) .\end{array}$ & & \\
\hline Leyh et al., 2018 [26] & $\begin{array}{l}\text { No effect on appetite sensations } \\
\qquad(p>0.05)\end{array}$ & $\begin{array}{l}\text { No effect on metabolism } \\
(p>0.05)\end{array}$ & & \\
\hline Madzima et al., 2018 [27] & & No effect on metabolism $(p>0.05)$ & $\begin{array}{c}24 \mathrm{~g} \text { casein had significantly lower } \\
(p=0.04) \text { fat oxidation compared to } \\
24 \mathrm{~g} \text { whey when measured } \\
\text { indirectly by RER. }\end{array}$ & \\
\hline Trommelen et al., 2018 [28] & $\begin{array}{l}\text { No effect on appetite sensations } \\
\qquad(p>0.05)\end{array}$ & & & $\begin{array}{l}\text { No effect on next-morning food } \\
\text { intake }(p>0.05) .\end{array}$ \\
\hline Allman et al., 2020 [29] & & $\begin{array}{l}\text { No effect on metabolism } \\
\qquad(p>0.05)\end{array}$ & No effect on lipolysis $(p>0.05)$ & \\
\hline \multicolumn{5}{|l|}{ Overweight/obese young adult } \\
\hline Kinsey et al., 2014 [21] & $\begin{array}{l}\text { No group } x \text { time interaction for any } \\
\text { appetite sensations }(p>0.05) . \\
\text { Significant main effect of } \\
\text { time interaction: } \\
\text { Increased satiety }(p=0.03) \\
\text { Reduced desire to eat }(p=0.006)\end{array}$ & $\begin{array}{l}\text { No time or group } x \text { time interaction } \\
\text { for RMR }(p>0.05) .\end{array}$ & & \\
\hline
\end{tabular}


Table 4. Cont.

\begin{tabular}{|c|c|c|c|c|}
\hline Study (Author, Year) & $\begin{array}{c}\text { Next-Morning Appetite, } \\
\text { Hunger, and Satiety }\end{array}$ & Metabolism & Lipolysis & Next-Morning Food Intake \\
\hline Ormsbee et al., 2015 [23] & $\begin{array}{l}\text { No effect on hunger or desire to eat } \\
\qquad(p>0.05) \text {. } \\
\text { Significant group x time interaction: } \\
\text { Casein increased morning satiety } \\
\text { compared to controls after } 4 \text { weeks } \\
\qquad(p=0.02) .\end{array}$ & $\begin{array}{c}\text { No group } \times \text { time interaction for } \\
\text { RMR }(p>0.05) . \\
\text { Not statistically significant } \\
(p=0.07) \text { but casein had greater } \\
\text { increases on RMR than in control. }\end{array}$ & & \\
\hline Kinsey et al., 2016 [24] & $\begin{array}{l}\text { No effect on hunger or satiety } \\
\qquad(p>0.05) \text {. } \\
\text { Significant group effect: } \\
\text { Casein increased desire to eat } \\
\text { compared to control }(p=0.03) \text {. }\end{array}$ & $\begin{array}{l}\text { No effect on metabolism } \\
\qquad(p>0.05)\end{array}$ & No effect on lipolysis $(p>0.05)$ & \\
\hline \multicolumn{5}{|l|}{ Overweight/obese young adult } \\
\hline Lay et al., 2018 [25] & $\begin{array}{l}\text { No effect on hunger or desire to eat } \\
\qquad(p>0.05) \text {. } \\
\text { Not statistically significant } \\
(p=0.07) \text { but casein had greater } \\
\text { increases on next-morning fullness. }\end{array}$ & $\begin{array}{l}\text { No effect on metabolism } \\
\qquad(p>0.05)\end{array}$ & & $\begin{array}{c}\text { No effect on next-morning food } \\
\text { intake }(p>0.05) .\end{array}$ \\
\hline \multicolumn{5}{|l|}{ Healthy elderly adult } \\
\hline Morehen et al., 2020 [30] & $\begin{array}{l}\text { No effect on appetite sensations } \\
\qquad(p>0.05)\end{array}$ & $\begin{array}{l}\text { No effect on metabolism } \\
\qquad(p>0.05) .\end{array}$ & & $\begin{array}{l}\text { No effect on next-morning food } \\
\text { intake }(p>0.05) .\end{array}$ \\
\hline
\end{tabular}


3.3. Effects of Pre-Sleep Casein Supplementation on Next-Day Appetite, Hunger, Satiety, and Next-Day Food Intake

Results of studies that observed the effect of casein on appetite sensations were notably influenced by the population involved. All studies in healthy and active young adults or active elderly adults $(n=7)$ found no significant effect on appetite sensations $(p>0.05)$. However, studies involving overweight or obese individuals noted conflicting findings.

Three of the four studies on overweight or obese individuals observed improvements in appetite sensations. Ormsbee et al. [23] noted that $30 \mathrm{~g}$ of pre-sleep casein consumption for 4 weeks resulted in a significant increase in morning satiety compared to $30 \mathrm{~g}$ of whey protein or $34 \mathrm{~g}$ of maltodextrin $(p=0.02)$. Kinsey et al. [21] also found a significant increase in morning satiety $(p=0.03)$ and a decrease in the desire to eat $(p=0.006)$ for $30 \mathrm{~g}$ of casein compared to $30 \mathrm{~g}$ of whey protein or $34 \mathrm{~g}$ of maltodextrin. Lay et al. [25] noted a greater increase on next-morning fullness for pre-sleep casein consumption compared to a non-nutritive control, but their data were not statistically significant $(p=0.07)$. It should be noted that Lay et al. did not use a standard casein protein formulation, but rather 2 skim milk powder mixtures that also included whey and carbohydrates (BS10 $=8 \mathrm{~g}$ casein, $2 \mathrm{~g}$ whey, 14 g carbohydrates; BS30 = 24 g casein, 6 g whey, 42 g carbohydrates). Only the study by Kinsey et al. [24] found an opposite effect on appetite, with $30 \mathrm{~g}$ of casein causing a significant increase in desire to eat $(p=0.03)$.

\subsection{Effects of Pre-Sleep Casein Supplementation on Energy Expenditure and Metabolic Rate}

None of the studies in healthy young adults or active elderly adults $(n=6)$ observed a significant difference $(p>0.05)$ in metabolism, except for one. Madzima et al. [22] found that when comparing two casein formulations ( $24 \mathrm{~g}$ or $48 \mathrm{~g}$ ) compared to two whey protein formulations ( $24 \mathrm{~g}$ or $48 \mathrm{~g}$ ) or one non-nutritive control, a significant change in VO2 was seen for the group that consumed casein.

In the studies with overweight or obese participants, no significant differences were found in metabolism either, but Ormsbee et al. [23] found a non-statistically significant $(p=0.07)$ increase in resting metabolic rate (RMR) in their casein group compared to their control group (see Table 4. Summary of main results from included studies related to pre-sleep casein supplementation effects on metabolism and appetite).

\subsection{Effects of Pre-Sleep Casein Supplementation on Lipolysis and Fat Oxidation}

Only three of the 11 studies observed the effects of pre-sleep casein supplementation on lipolysis in either healthy young adults or overweight and obese young adults.

Two of the three studies used $30 \mathrm{~g}$ of casein for their experimental trial and found no significant differences $(p>0.05)$ in fat oxidation. These studies measured lipolysis in subcutaneous abdominal adipose tissue (SCAAT) directly through microdialysis, which monitors interstitial glycerol concentrations over an extended period of time.

Madzima et al. [27] found a significant decrease $(p=0.04)$ in fat oxidation in healthy young adults when comparing their $24 \mathrm{~g}$ casein group to their $24 \mathrm{~g}$ whey protein group, but there was no significant difference between the casein group compared to the placebo group. Their protocol measured fat oxidation indirectly through respiratory exchange ratio from the same metabolic cart and a ventilated hood setup used for indirect calorimetry.

\section{Discussion}

This systematic review investigated the effects of pre-sleep casein supplementation on metabolic and appetite parameters. A summary of the main findings indicates that ingesting 24-48 g of casein 30 min before sleep does not suppress next-day appetite sensations and food intake in healthy young adults. Effects on appetite sensations and food intake in overweight or obese populations are unclear, as findings are conflicting, and a definitive relationship cannot be stated on whether pre-sleep casein supplementation increases or decreases next-day appetite and food intake. No effects on metabolic parameters were observed in overweight or obese populations or healthy elderly adults. Although there are 
some beneficial findings of pre-sleep casein supplementation on energy expenditure and lipolysis in healthy young adults, findings are limited, and more studies will be needed to elucidate these results. Furthermore, only one selected study in this systematic review included a healthy adult elderly population, limiting the representation of these findings to a fairly small sample size. These results support the efficacy of pre-sleep casein supplementation as a means to enhance muscular adaptations in a healthy active population without causing unwanted metabolic responses. However, further research is needed to clarify the potential utilization of this strategy for limiting weight gain in overweight or obese individuals.

This is relatively important for individuals trying to maximize muscle mass gain but should not be considered the most optimal strategy. It is important to know that protein distribution spread evenly throughout the day is associated with higher muscle mass [32]. One study [33] showed that evenly distributed protein intake in healthy adults significantly increased total daily mixed muscle protein fractional synthesis rate by up to $25 \%$ compared to an uneven protein intake distribution. Therefore, pre-sleep casein supplementation serves as an additional feeding window for extending protein distribution evenly throughout the day, theoretically creating a longer period of elevated muscle protein synthesis (MPS) for muscular adaptation. However, one study [34] noted that optimizing protein distribution throughout the day is less important compared to optimizing total daily protein intake primarily. Taking this into consideration, individuals trying to maximize muscular adaptation to resistance training should focus foremost on meeting adequate total protein intake of $0.8-1.3 \mathrm{~g} / \mathrm{kg} /$ day [34] before considering this pre-sleep protein supplementation strategy.

Furthermore, pre-sleep casein supplementation might not be the best protein choice for meeting general protein requirements in all healthy individuals trying to maximize adaptations to resistance training. Although casein elicits a similar MPS response regardless of age in a healthy population [35], whey protein typically stimulates a greater MPS response at rest and after resistance exercise [36]. This in part is due to whey's ability to elevate plasma amino acid concentrations to a greater extent than casein [36,37]. In addition, whey protein is characterized by faster digestion, better absorption kinetics, and greater total leucine content [38]. These gastrointestinal and protein characteristics are advantageous for maximizing short-term MPS response, since whey stimulates a greater peak MPS elevation within the first 1 to $3 \mathrm{~h}$ after consumption before gradually declining [39]. During the day, food is readily available and can be consumed around the same time MPS starts to decrease, so that maximal MPS response remains constant for long periods of time. In comparison, casein elicits slower gastrointestinal responses via gastric emptying, which is up to two times slower than whey protein [40]. Although the peak elevation of MPS response in casein is lower than whey within 1 to $3 \mathrm{~h}$ after food intake, casein can sustain a greater average peak MPS response over a $6 \mathrm{~h}$ time frame after initial food intake [39]. These influencing determinants reinforce casein as the optimal protein choice for consumption during nighttime feeding, since sleep creates a restrictive time frame where access to feeding for maximizing MPS is not feasible.

The findings of this systematic review also provide a differing perspective on nighttime snacking or eating, which has previously shown detrimental effects depending on the food being consumed. One study observed a significant decrease in fat oxidation but no significant changes in energy intake, energy expenditure, or body weight when food consumed was primarily carbohydrate and fat (mean protein/fat/carbohydrate ratio composition of $\mathrm{a} \approx 200 \mathrm{kcal}$ snack was 5:50:45) [41]. The findings of this systematic review further support that some of the detrimental effects of nighttime feeding can be negated with single macronutrient consumption, specifically protein. Pre-sleep casein supplementation can be implemented as an adjunct strategy for obese or overweight individuals to meet the entirety of a high-protein diet, which shows beneficial effects on all parameters regarding whole-day "satiety, thermogenesis, sleeping metabolic rate, protein balance, and fat oxidation" [42]. The beneficial effects on appetite and food intake even occur when 
hormonal responses such as decreased leptin and increased ghrelin occur [43]. Beneficial effects of high protein intake are not exclusive to total daily intake, as these effects have even been seen in single high-protein meals as well [44]. Milk proteins are one of the most optimal protein sources when trying to blunt hunger, as they improve satiety through the modulation of gastric emptying [40]. Specific to the timing of casein intake, it may also be a more beneficial nighttime snack option than whey protein because of its greater satiety effects [45]. Even at breakfast, high-casein meals display beneficial effects on appetite [46]. With these considerations, overweight or obese individuals can structure high-protein meal intake around times when the strongest appetite sensations occur. Therefore, pre-sleep casein supplementation may be an effective strategy for overweight or obese individuals who typically experience greater sensations of hunger at night.

Pre-sleep casein supplementation also shows potential benefits for meeting protein requirements in elderly individuals. The elderly population is at heightened risk of sarcopenia, which can limit mobility [47] and can also elevate risk of mortality [48]. It is important to understand that aging introduces additional factors that can negatively affect the efficacy of resistance training for maintaining lean mass and strength. Aging is associated with a weaker MPS response to dietary protein intake [49] and a decrease in both appetite and energy intake [50]. These physiological changes are important to understand in the context of optimal protein dosage for stimulating maximal MPS, as higher intakes are required in older adults compared to younger adults [49]. Supplementing daily intake in this population with nighttime protein feeding presents a possible solution to the physiological obstacles that elderly individuals face.

The main findings from this systematic review support the efficacy of pre-sleep casein supplementation, but limitations of the included studies should still be taken into consideration. Only half of the studies had meal standardization, which may have evoked undetected effects on the results obtained in the studies that did not include such standardization. Furthermore, the application of pre-sleep casein supplementation in research is typically focused around beneficial adaptations during resistance training, but fewer than half of the studies included an exercise component within their protocol. This is an important consideration, as higher doses of up to $40 \mathrm{~g}$ compared to 20-30 g of casein have clearly been shown to increase utilization within muscle protein synthesis overnight and to an even greater extent when combined with resistance training [51]. Another limitation to take into consideration is the food source that provided casein. Most studies used a liquid formulation of micellar casein with only a few studies providing casein in a mixed formulation with other macronutrients or as cottage cheese. The consumption of casein alone typically has a lower effect on appetite regulation than actual milk [52]. Future research should use a broader sample population to address these limitations. Only one study was in healthy elderly individuals, and no study was done in an overweight or obese elderly population. Lastly, only one study looked at the chronic effect of casein supplementation over the span of several weeks compared to the acute effects observed in most of the studies. Future research should be directed toward addressing these limitations through the incorporation of meal standardization and resistance training protocols, consumption of casein through different food sources, greater inclusion of healthy and unhealthy elderly adults, and analysis of chronic pre-sleep casein supplementation.

\section{Conclusions}

The findings of this systematic review show an overall trend of limited to no effect of pre-sleep casein supplementation on metabolic or appetite parameters in healthy and unhealthy populations. All findings from this systematic review should be interpreted with caution, as data are limited, and future research is needed to clarify the relationships observed.

Author Contributions: J.D.C. contributed to the conceptualization, methodology, bibliographic search, literature review, selection of papers included, original draft preparation, and writing the review. D.K. contributed to the editing process of the systematic review draft for submission. All authors have read and agreed to the published version of the manuscript. 
Funding: This research received no external funding.

Institutional Review Board Statement: Not applicable.

Informed Consent Statement: Not applicable.

Data Availability Statement: Data sharing not applicable.

Conflicts of Interest: The authors declare no conflict of interest.

\section{References}

1. de Castro, J.M. The time of day of food intake influences overall intake in humans. J. Nutr. 2004, 134, 104-111. [CrossRef] [PubMed]

2. de Castro, J.M. The time of day and the proportions of macronutrients eaten are related to total daily food intake. Br. J. Nutr. 2007, 98, 1077-1083. [CrossRef] [PubMed]

3. Andersen, G.S.; Stunkard, A.J.; Sørensen, T.I.A.; Petersen, L.; Heitmann, B.L. Night eating and weight change in middle-aged men and women. Int. J. Obes. Relat. Metab. Disord. 2004, 28, 1338-1343. [CrossRef]

4. Van Cauter, E.; Polonsky, K.S.; Scheen, A.J. Roles of circadian rhythmicity and sleep in human glucose regulation. Endocr. Rev. 1997, 18, 716-738.

5. Zitting, K.-M.; Vujovic, N.; Yuan, R.K.; Isherwood, C.M.; Medina, J.E.; Wang, W.; Buxton, O.M.; Williams, J.S.; Czeisler, C.A.; Duffy, J.F. Human resting energy expenditure varies with circadian phase. Curr. Biol. 2018, 28, 3685-3690.e3. [CrossRef]

6. de Zwaan, M.; Burgard, M.A.; Schenck, C.H.; Mitchell, J.E. Night time eating: A review of the literature. Eur. Eat. Disord. Rev. 2003, 11, 7-24. [CrossRef]

7. Katayose, Y.; Tasaki, M.; Ogata, H.; Nakata, Y.; Tokuyama, K.; Satoh, M. Metabolic rate and fuel utilization during sleep assessed by whole-body indirect calorimetry. Metabolism 2009, 58, 920-926. [CrossRef]

8. Gluck, M.E.; Venti, C.A.; Salbe, A.D.; Votruba, S.B.; Krakoff, J. Higher 24-h respiratory quotient and higher spontaneous physical activity in nighttime eaters. Obesity (Silver Spring) 2011, 19, 319-323. [CrossRef] [PubMed]

9. Kinsey, A.W.; Ormsbee, M.J. The health impact of nighttime eating: Old and new perspectives. Nutrients 2015, 7, $2648-2662$. [CrossRef]

10. Koopman, R.; Wagenmakers, A.J.M.; Manders, R.J.F.; Zorenc, A.H.G.; Senden, J.M.G.; Gorselink, M.; Keizer, H.A.; van Loon, L.J.C. Combined ingestion of protein and free leucine with carbohydrate increases postexercise muscle protein synthesis in vivo in male subjects. Am. J. Physiol. Endocrinol. Metab. 2005, 288, E645-E653. [CrossRef]

11. Res, P.T.; Groen, B.; Pennings, B.; Beelen, M.; Wallis, G.A.; Gijsen, A.P.; Senden, J.M.G.; VAN Loon, L.J.C. Protein ingestion before sleep improves postexercise overnight recovery. Med. Sci. Sports Exerc. 2012, 44, 1560-1569. [CrossRef] [PubMed]

12. Kouw, I.W.; Holwerda, A.M.; Trommelen, J.; Kramer, I.F.; Bastiaanse, J.; Halson, S.L.; Wodzig, W.K.; Verdijk, L.B.; van Loon, L.J Protein ingestion before sleep increases overnight muscle protein synthesis rates in healthy older men: A randomized controlled trial. J. Nutr. 2017, 147, 2252-2261. [CrossRef]

13. Trommelen, J.; Holwerda, A.M.; Senden, J.M.; Goessens, J.P.B.; VAN Kranenburg, J.; Gijsen, A.P.; Verdijk, L.B.; VAN Loon, L.J.C. Casein Ingestion Does Not Increase Muscle Connective Tissue Protein Synthesis Rates. Med. Sci. Sports Exerc. 2020, 52, $1983-1991$. [CrossRef]

14. Holwerda, A.M.; Kouw, I.W.K.; Trommelen, J.; Halson, S.L.; Wodzig, W.K.; Verdijk, L.B.; van Loon, L.J.C. Physical activity performed in the evening increases the overnight muscle protein synthetic response to presleep protein ingestion in older men. J. Nutr. 2016, 146, 1307-1314. [CrossRef] [PubMed]

15. Snijders, T.; Res, P.T.; Smeets, J.S.J.; van Vliet, S.; van Kranenburg, J.; Maase, K.; Kies, A.K.; Verdijk, L.B.; van Loon, L.J.C. Protein ingestion before sleep increases muscle mass and strength gains during prolonged resistance-type exercise training in healthy young men. J. Nutr. 2015, 145, 1178-1184. [CrossRef] [PubMed]

16. Antonio, J.; Ellerbroek, A.; Peacock, C.; Silver, T. Casein protein supplementation in trained men and women: Morning versus evening. Int. J. Exerc. Sci. 2017, 10, 479-486.

17. Reis, C.E.G.; Loureiro, L.M.R.; Roschel, H.; da Costa, T.H.M. Effects of pre-sleep protein consumption on muscle-related outcomes: A systematic review. J. Sci. Med. Sport 2021, 24, 177-182. [CrossRef]

18. Dougkas, A.; Minihane, A.M.; Givens, D.I.; Reynolds, C.K.; Yaqoob, P. Differential effects of dairy snacks on appetite, but not overall energy intake. Br. J. Nutr. 2012, 108, 2274-2285. [CrossRef]

19. de Cássia Gonçalves Alfenas, R.; Bressan, J.; de Paiva, A.C. Effects of protein quality on appetite and energy metabolism in normal weight subjects. Arq. Bras. Endocrinol. Metabol. 2010, 54, 45-51. [CrossRef]

20. Bowen, J.; Noakes, M.; Trenerry, C.; Clifton, P.M. Energy intake, ghrelin, and cholecystokinin after different carbohydrate and protein preloads in overweight men. J. Clin. Endocrinol. Metab. 2006, 91, 1477-1483. [CrossRef]

21. Kinsey, A.W.; Eddy, W.R.; Madzima, T.A.; Panton, L.B.; Arciero, P.J.; Kim, J.-S.; Ormsbee, M.J. Influence of night-time protein and carbohydrate intake on appetite and cardiometabolic risk in sedentary overweight and obese women. Br. J. Nutr. 2014, 112, 320-327. [CrossRef] [PubMed]

22. Madzima, T.A.; Panton, L.B.; Fretti, S.K.; Kinsey, A.W.; Ormsbee, M.J. Night-time consumption of protein or carbohydrate results in increased morning resting energy expenditure in active college-aged men. Br. J. Nutr. 2014, 111, 71-77. [CrossRef] 
23. Ormsbee, M.J.; Kinsey, A.W.; Eddy, W.R.; Madzima, T.A.; Arciero, P.J.; Figueroa, A.; Panton, L.B. The influence of nighttime feeding of carbohydrate or protein combined with exercise training on appetite and cardiometabolic risk in young obese women. Appl. Physiol. Nutr. Metab. 2015, 40,37-45. [CrossRef] [PubMed]

24. Kinsey, A.W.; Cappadona, S.R.; Panton, L.B.; Allman, B.R.; Contreras, R.J.; Hickner, R.C.; Ormsbee, M.J. The effect of casein protein prior to sleep on fat metabolism in obese men. Nutrients 2016, 8, 452. [CrossRef] [PubMed]

25. Lay, A.H.H.; Crabtree, D.R.; Campbell, T.G.; Dreczkowski, G.M.; Galloway, S.D.R.; Tipton, K.D.; Witard, O.C. A bedtime milk snack does not impact RMR, substrate utilisation and appetite the following morning in mildly overweight males. Br. J. Nutr. 2018, 119, 1355-1365. [CrossRef]

26. Leyh, S.M.; Willingham, B.D.; Baur, D.A.; Panton, L.B.; Ormsbee, M.J. Pre-sleep protein in casein supplement or whole-food form has no impact on resting energy expenditure or hunger in women. Br. J. Nutr. 2018, 120, 988-994. [CrossRef]

27. Madzima, T.A.; Melanson, J.T.; Black, J.R.; Nepocatych, S. Pre-sleep consumption of casein and whey protein: Effects on morning metabolism and resistance exercise performance in active women. Nutrients 2018, 10, 1273. [CrossRef]

28. Trommelen, J.; Kouw, I.W.K.; Holwerda, A.M.; Snijders, T.; Halson, S.L.; Rollo, I.; Verdijk, L.B.; van Loon, L.J.C. Presleep dietary protein-derived amino acids are incorporated in myofibrillar protein during postexercise overnight recovery. Am. J. Physiol. Endocrinol. Metab. 2018, 314, E457-E467. [CrossRef]

29. Allman, B.R.; Morrissey, M.C.; Kim, J.-S.; Panton, L.B.; Contreras, R.J.; Hickner, R.C.; Ormsbee, M.J. Lipolysis and fat oxidation are not altered with presleep compared with daytime casein protein intake in resistance-trained women. J. Nutr. 2020, 150, 47-54 [CrossRef] [PubMed]

30. Morehen, S.; Smeuninx, B.; Perkins, M.; Morgan, P.; Breen, L. Pre-sleep casein protein ingestion does not impact next-day appetite, energy intake and metabolism in older individuals. Nutrients 2019, 12, 90. [CrossRef]

31. Nelson, H.; Valladão, S.P.; Schwarz, N.; Valliant, M.; Thomas, L.A. Effect of pre-sleep casein and tryptophan supplementation on energy expenditure before, during, and after exercise in active females. J. Ex. Nutr. 2021, 4.

32. Jespersen, S.E.; Agergaard, J. Evenness of dietary protein distribution is associated with higher muscle mass but not muscle strength or protein turnover in healthy adults: A systematic review. Eur. J. Nutr. 2021, 1-18.

33. Mamerow, M.M.; Mettler, J.A.; English, K.L.; Casperson, S.L.; Arentson-Lantz, E.; Sheffield-Moore, M.; Layman, D.K.; Paddon-Jones, D. Dietary protein distribution positively influences $24-\mathrm{h}$ muscle protein synthesis in healthy adults. J. Nutr. 2014, 144, 876-880. [CrossRef]

34. Hudson, J.L.; Iii, R.E.B.; Campbell, W.W. Protein distribution and muscle-related outcomes: Does the evidence support the concept? Nutrients 2020, 12, 1441. [CrossRef] [PubMed]

35. Koopman, R.; Walrand, S.; Beelen, M.; Gijsen, A.P.; Kies, A.K.; Boirie, Y.; Saris, W.H.M.; van Loon, L.J.C. Dietary protein digestion and absorption rates and the subsequent postprandial muscle protein synthetic response do not differ between young and elderly men. J. Nutr. 2009, 139, 1707-1713. [CrossRef]

36. Tang, J.E.; Moore, D.R.; Kujbida, G.W.; Tarnopolsky, M.A.; Phillips, S.M. Ingestion of whey hydrolysate, casein, or soy protein isolate: Effects on mixed muscle protein synthesis at rest and following resistance exercise in young men. J. Appl. Physiol. 2009, 107, 987-992. [CrossRef]

37. Hall, W.L.; Millward, D.J.; Long, S.J.; Morgan, L.M. Casein and whey exert different effects on plasma amino acid profiles, gastrointestinal hormone secretion and appetite. Br. J. Nutr. 2003, 89, 239-248. [CrossRef] [PubMed]

38. Pennings, B.; Boirie, Y.; Senden, J.M.G.; Gijsen, A.P.; Kuipers, H.; van Loon, L.J.C. Whey protein stimulates postprandial muscle protein accretion more effectively than do casein and casein hydrolysate in older men. Am. J. Clin. Nutr. 2011, 93, 997-1005. [CrossRef]

39. Reitelseder, S.; Agergaard, J.; Doessing, S.; Helmark, I.C.; Lund, P.; Kristensen, N.B.; Frystyk, J.; Flyvbjerg, A.; Schjerling, P.; van Hall, G.; et al. Whey and casein labeled with 1-[1-13c]leucine and muscle protein synthesis: Effect of resistance exercise and protein ingestion. Am. J. Physiol. Endocrinol. Metab. 2011, 300, E231-E242. [CrossRef] [PubMed]

40. Marsset-Baglieri, A.; Fromentin, G.; Airinei, G.; Pedersen, C.; Léonil, J.; Piedcoq, J.; Rémond, D.; Benamouzig, R.; Tomé, D.; Gaudichon, C. Milk protein fractions moderately extend the duration of satiety compared with carbohydrates independently of their digestive kinetics in overweight subjects. Br. J. Nutr. 2014, 112, 557-564. [CrossRef] [PubMed]

41. Hibi, M.; Masumoto, A.; Naito, Y.; Kiuchi, K.; Yoshimoto, Y.; Matsumoto, M.; Katashima, M.; Oka, J.; Ikemoto, S. Nighttime snacking reduces whole body fat oxidation and increases ldl cholesterol in healthy young women. Am. J. Physiol. Regul. Integr. Comp. Physiol. 2013, 304, R94-R101. [CrossRef] [PubMed]

42. Lejeune, M.P.G.M.; Westerterp, K.R.; Adam, T.C.M.; Luscombe-Marsh, N.D.; Westerterp-Plantenga, M.S. Ghrelin and glucagonlike peptide 1 concentrations, 24-h satiety, and energy and substrate metabolism during a high-protein diet and measured in a respiration chamber. Am. J. Clin. Nutr. 2006, 83, 89-94. [CrossRef] [PubMed]

43. Weigle, D.S.; Breen, P.A.; Matthys, C.C.; Callahan, H.S.; Meeuws, K.E.; Burden, V.R.; Purnell, J.Q. A high-protein diet induces sustained reductions in appetite, ad libitum caloric intake, and body weight despite compensatory changes in diurnal plasma leptin and ghrelin concentrations. Am. J. Clin. Nutr. 2005, 82, 41-48. [CrossRef] [PubMed]

44. Smeets, A.J.; Soenen, S.; Luscombe-Marsh, N.D.; Ueland, Ø.; Westerterp-Plantenga, M.S. Energy expenditure, satiety, and plasma ghrelin, glucagon-like peptide 1 , and peptide tyrosine-tyrosine concentrations following a single high-protein lunch. J. Nutr. 2008, 138, 698-702. [CrossRef] [PubMed] 
45. Acheson, K.J.; Blondel-Lubrano, A.; Oguey-Araymon, S.; Beaumont, M.; Emady-Azar, S.; Ammon-Zufferey, C.; Monnard, I.; Pinaud, S.; Nielsen-Moennoz, C.; Bovetto, L. Protein choices targeting thermogenesis and metabolism. Am. J. Clin. Nutr. 2011, 93, 525-534. [CrossRef]

46. Veldhorst, M.A.B.; Nieuwenhuizen, A.G.; Hochstenbach-Waelen, A.; Westerterp, K.R.; Engelen, M.P.K.J.; Brummer, R.-J.M.; Deutz, N.E.P.; Westerterp-Plantenga, M.S. Comparison of the effects of a high- and normal-casein breakfast on satiety, "satiety" hormones, plasma amino acids and subsequent energy intake. Br. J. Nutr. 2009, 101, 295-303. [CrossRef]

47. Dufour, A.B.; Hannan, M.T.; Murabito, J.M.; Kiel, D.P.; McLean, R.R. Sarcopenia definitions considering body size and fat mass are associated with mobility limitations: The Framingham Study. J. Gerontol. A Biol. Sci. Med. Sci. 2013, 68, 168-174. [CrossRef]

48. Landi, F.; Liperoti, R.; Fusco, D.; Mastropaolo, S.; Quattrociocchi, D.; Proia, A.; Tosato, M.; Bernabei, R.; Onder, G. Sarcopenia and mortality among older nursing home residents. J. Am. Med. Dir. Assoc. 2012, 13, 121-126. [CrossRef]

49. Witard, O.C.; Wardle, S.L.; Macnaughton, L.S.; Hodgson, A.B.; Tipton, K.D. Protein considerations for optimising skeletal muscle mass in healthy young and older adults. Nutrients 2016, 8, 181. [CrossRef]

50. Giezenaar, C.; Chapman, I.; Luscombe-Marsh, N.; Feinle-Bisset, C.; Horowitz, M.; Soenen, S. Ageing is associated with decreases in appetite and energy intake-A meta-analysis in healthy adults. Nutrients 2016, 8, 28. [CrossRef] [PubMed]

51. Snijders, T.; Trommelen, J.; Kouw, I.W.K.; Holwerda, A.M.; Verdijk, L.B.; van Loon, L.J.C. The impact of pre-sleep protein ingestion on the skeletal muscle adaptive response to exercise in humans: An update. Front. Nutr. 2019, 6, 17. [CrossRef] [PubMed]

52. Lorenzen, J.; Frederiksen, R.; Hoppe, C.; Hvid, R.; Astrup, A. The effect of milk proteins on appetite regulation and diet-induced thermogenesis. Eur. J. Clin. Nutr. 2012, 66, 622-627. [CrossRef] [PubMed] 